\title{
Evaluation of Bacteria from Soil and Rhizosphere as Herbicidal Candidates of Some Broadleaf Weeds
}

\author{
Merhan M. Tawfik ${ }^{(1)}$, Nevin A. Ibrahim(2), Mohamed A. Balah ${ }^{(1)}$, Mohamed M. \\ Abouzeid $^{(2)}$ \\ (1) Plant Protection Department, Desert Research Center, El-Matariya, Cairo, Egypt; \\ ${ }^{(2)}$ Department of Microbiology, Faculty of Science, Ain Shams University, Cairo, \\ Egypt.
}

\begin{abstract}
THE USE of bacteria in biological weed control is an alternative ecofriendly way to tackle weed problems and reduce the risk of herbicide resistance. In this study, we obtained four main active bacterial isolates under the genera Pseudomonas, Bacillus and Xanthomonas from Wadi El Natroun region. All the tested bacterial isolates caused high significant reductions in seed germination and seedling growth of Convolvulus arvensis and Portulaca oleracea. Bioassaying ethyl acetate crude extracts of these isolates showed that Pseudomonas sp. (isolate 1) was the most active against seedling stage of Portulaca oleracea. The cultural filtrate of the same isolate caused $100 \%$ reduction when assayed on seed germination, shoot and root length of Convolvulus arvensis and Portulaca oleracea. At the highest concentration $(40 \mathrm{mg} / \mathrm{ml})$ of the crude ethyl acetate extract, the reduction percentage in total biomass fresh weights of Portulaca oleracea and Convolvulus arvensis seedlings reached 71.27 and $39.37 \%$, respectively. The $\mathrm{EC}_{50}$ values (concentration that inhibited growth by $50 \%$ ) were 1.3 and $1.64 \mathrm{mg} / \mathrm{ml}$ for Portulaca oleracea and Convolvulus arvensis, respectively. Comparative 16S rRNA gene sequencing analysis and biochemical characterization demonstrated that isolate FS15 was member of the genus Pseudomonas and belongs to the Pseudomonas aeruginosa group with Pseudomonas aeruginosa strain NR 113599.1 as the closest relative (99.5\% sequence similarity). In conclusion, Pseudomonas aeruginosa has high potential to be developed as natural bacterial herbicide and may be used in broadleaf weed control.
\end{abstract}

Keywords: Rhizobacteria, Biocontrol agent, Pseudomonas aeruginosa, Noxious weeds, Bioherbicides.

\section{Introduction}

Weeds are unwanted plants that compete with crop plants for space, nutrients, water, sunlight, and other elements. They are under estimated crop pests causing approximately 37\% losses in the yields of crops (Sindhu \& Sehrawat, 2017 and Ferreira \& Reinhardt, 2016). According to Holm et al. (1991) Convolvulus arvensis is one of the world's top noxious weeds and it is found in 32 different crops in 54 countries. Meanwhile, Portulaca oleracea is listed as a very aggressive noxious weed infesting gardens, wetlands, lawns and agricultural areas (Smith \& Figueiredo, 2010) and has been ranked the eighth most common weed in the world (Moneim et al., 2013).

Weed management in recent decades is changing from conventional practices to the use of environment friendly classical biological and bioherbicidal weed control approaches in crop production (Javaid, 2010 and Javaid \& Ali, 2011). Interest in developing effective biological weed management systems continues to increase because of a growing awareness of problems associated with the constant and intensive use of chemical herbicides. Most herbicides cause some visible stress to crops and non-target organisms, damage surface and ground water, raise resistance in weeds, capable of entering the body via food chain threating human and animal health (Gliessman, 2002 and Kremer, 2006). Microbial based weed control of which soil microorganisms is part represents an innovative means to manage troublesome weeds. Application of naturally occurring plant suppressive microbes that are found in soil has recently received considerable attention, as a promising approach for controlling weeds by providing healthy/ economically sounder herbicides and a limited chance of developing herbicides-resistant weeds

\footnotetext{
"Corresponding author email: merhangalal@yahoo.com DOI: 10.21608/ejbo.2018.4172.1186 
(Weissmann \& Gerhardson, 2001; Omer et al., 2010 and Radhakrishnan et al., 2016).

Rhizosphere microorganisms have been found to suppress the growth of weeds by reducing plant density, biomass and seed production. Bacteria produce a wide array of phytotoxins that may cause mortality of weed plants (Sindhu \& Sehrawat, 2017). The object of deleterious rhizobacteria is not to completely kill or eradicate the weed population; but rather to reduce the competitive pressure of the weed leading to decrease in their biomass accumulation and reduction in seed production (Kremer, 2006). Utilizing rhizospheric bacterial isolates to inhibit growth of weeds but not that of crop plants will benefit agriculture by contributing to increased crop yields and reducing weed competition (Patil, 2014).

Biological control is still extremely limited in weed control applications; this study focuses on using bacteria which received less attention than using fungi in controlling broadleaved weeds. The study aimed to increase the biological sources of bioherbicides by screening rhizospheric and soil bacteria that have potential herbicidal activity using Convolvulus arvensis and Portulaca oleracea as test organisms.

\section{Materials and Methods}

\section{Bacterial isolation from soil}

Bacteria were isolated from nine types of rhizosphere and non-rhizosphere soils (bulk soil) of Convolvulus arvensis, Typha sp., Melilotus indica, Cortaderia selloana, Echinochloa colonum, Cynodon sp., Malva sp., Chenopodium sp. and Cyperus rotundus at Wadi El Natroun region, Egypt during January 2016. After collection, soil samples were kept in refrigerator at $4^{\circ} \mathrm{C}$ until investigation. The isolation of bacteria was processed by serial dilution method according to Johnston \& Booth (1983). Pure bacterial culture colonies were maintained on nutrient agar (NA) slants at $4^{\circ} \mathrm{C}$ for testing further studies.

\section{Effect of bacterial culture filtrate on Convolvulus arvensis and Portulaca oleracea seeds}

The cell free culture filtrate of bacteria was prepared by culturing bacterial isolates on NA medium and incubated at $30^{\circ} \mathrm{C}$ for $24-48 \mathrm{hr}$ according to Landa et al. (1997). A suspension of each bacterial isolate was prepared and inoculated into a $250 \mathrm{ml}$ Erlenmeyer flask containing $100 \mathrm{ml}$ nutrient broth (NB) in a shaking incubator (Daihan scientific WIS-30) at $120 \mathrm{rpm}$ and $30^{\circ} \mathrm{C}$ for two days. The broth was centrifuged under cooling to remove bacterial cells then, the supernatant was filtered through sterile $0.45 \mu \mathrm{m}$ pore size Millipore filters (Millex syring filter). All supernatants were collected and stored at $4^{\circ} \mathrm{C}$ until bioassay tests. The seeds of Convolvulus arvensis and Portulaca oleracea were surface sterilized by soaking in $0.5 \%$ sodium hypochlorite $(\mathrm{NaOCl})$ for $2 \mathrm{~min}$ followed by rinsing thoroughly in sterile distilled water and plotted on filter paper then drying under a laminar flow hood. The sterilized seeds ( 5 seeds per dish) were sprinkled in sterile $9 \mathrm{~cm}$ diameter petri dishes containing sterile filter paper and $5 \mathrm{ml}$ of cultural filtrate was added under aseptic conditions. Controls were inoculated with $5 \mathrm{ml}$ of non-inoculated sterile media. Petri dishes were sealed with parafilm and incubated in darkness at $25 \pm 2{ }^{\circ} \mathrm{C}$. Three replicates were used for each treatment. The germination and seedling (root and shoot length) responses were determined 7 days after incubation.

\section{Preliminary identification of active bacterial isolates}

Bacterial isolates that inhibited the target weeds under laboratory conditions were morphologically characterized using standard microbiological methods for Gram-reaction to differentiate $G$ +ve from $G$-ve bacteria and then biochemically characterized using motility, catalase, urease, citrate, nitrate reduction and oxidase production (Prescot et al., 1993).

Bioassay of bacterial crude extracts on Convolvulus arvensis and Portulaca oleracea seedlings

Active culture filtrates were adjusted to $\mathrm{pH}$ 3.8 then extracted 3 times with an equal volume of ethyl acetate. Extracts were then completely dried using a rotary evaporator to give crude oily residues, which were re-dissolved in $10 \%$ ethanol from which a series of concentrations ( 5 , $10,20,30,40 \mathrm{mg} / \mathrm{ml})$ were prepared. Prepared concentrations were added into tissue culture tubes containing $3 \mathrm{ml}$ of liquid Murashige \& Skoog medium (MS medium) where the roots of seven days old seedlings were submerged (one seedling per tube). Three replicates were used for each concentration. After incubation at $25^{\circ} \mathrm{C}$ 
for seven days, the seedlings were removed, biomass fresh weights were measured and the reduction percentage ( $\mathrm{R} \%$ ) was calculated (Balah, 2012).

\section{Molecular identification of the most active isolate}

The 16S rDNA gene analysis of the most active isolate was carried out using MicroSeq 500 system. Amplification of $500 \mathrm{bp}$ of $16 \mathrm{~S}$ rRNA gene using GeneAmp 9600 thermocycler (Applied Biosystems). Amplicon detection was verified by $2 \%$ agarose gel electrophoresis previous purification with YM-100 Microconcentrators (Celera Diagnostics). The sequencing reactions were performed with MicroSeq500 16S rDNA. Bacterial Identification Sequencing kit, cycle reactions were purified using Centri-Sep Spin Columns (Applied Biosystems) and the cycle sequencing products were analysed on 3130 Genetic Analyzer (Applied Biosystems) according to the manufacturer's instructions. Sequences from both strands were aligned by using NCBI BLAST 2 Sequence. Then phylogenetic tree was constructed according to Saitou \&Nei (1987) using MEGA 5.0 Molecular Evolutionary Genetics Analysis software version 5 (Tamura et al., 2011).

Statistical analysis of results

Data of Randomized Complete Block Design experiments were statistically analyzed by ANOVA according to Snedecor \& Cochran (1990) and treatment means were compared by LSD test at $5 \%$ level of probability using CoStat. The $\mathrm{EC}_{50}$ values (half maximal effective concentration) for growth parameter were calculated by plotting concentration on a log scale (X) and the response (Y) on probit scale mathematically transformed, the data appear linear and sign the point in a semi-log graph paper.

\section{Results}

Herbicidal activity of bacterial isolates culture filtrate

Screening of a total of 40 bacterial isolates on seed germination of Convolvulus arvensis and Portulaca oleracea lead to four main active isolates (FS15, PS, BRS2, and BS47). The selection of these four active isolates was based on reduction percentage of germination, shoot length, and root length over $70 \%$, the results of the rest of isolates was not reported. The source and isolation site of the selected bacteria are shown in Table 1. The application of four bacterial culture filtrates on Convolvulus arvensis seeds resulted in a complete inhibition on the germination (\%) compared to the untreated control concurrently with a significant reduction in length of shoot and root. While, in case of Portulaca oleracea, 3 isolates (FS15, PS and BS47) gave 100\% reduction in germination, shoot length and root length while the fourth isolate BRS2 gave 75\% inhibition in seed germination and 89.34\%, and $73.68 \%$ reduction in shoot and root length, respectively as shown in Table 1 .

TABLE 1. Source and location of active bacterial isolates and their effect on Convolvulus arvensis and Portulaca oleracea.

\begin{tabular}{|c|c|c|c|c|c|c|c|c|}
\hline $\begin{array}{l}\text { Bacterial } \\
\text { isolate code }\end{array}$ & Source of isolation & Location & \multicolumn{3}{|c|}{$\begin{array}{c}\text { Reduction \% on } \\
\text { Convolvulus arvensis }\end{array}$} & \multicolumn{3}{|c|}{$\begin{array}{l}\text { Reduction \% on } \\
\text { Portulaca oleracea }\end{array}$} \\
\hline FS15 & Soil of Chenopodium sp. & Natural vegetation & ++ & ++ & ++ & ++ & ++ & ++ \\
\hline PS & Soil of Convolvulus arvensis & Sugar beet farm & ++ & ++ & ++ & ++ & ++ & ++ \\
\hline BRS2 & Rhizosphere of Cynodon sp. & Sugar beet farm & ++ & ++ & ++ & + & + & + \\
\hline
\end{tabular}

$\mathrm{G}=$ Germination, $\mathrm{SL}=$ Shoot length, $\mathrm{RL}=$ Root length.

$(++)$ Represents $100 \%$ reduction, $(+)$ means reduction more than $70 \%$. 
Preliminary identification of main active bacterial isolates

Preliminary morphologically identification of the 4 selected isolates showed FS15, PS and BS47 are gram negative bacilli while BRS2 gram positive bacilli. Biochemical tests demonstrated that 2 isolates (FS15 and PS) were members of the genus Pseudomonas whereas the other two (BS21 and BS47) were shown to belong to the genus Bacillus and Xanthomonas sp., respectively (Table 2 ).

Herbicidal potential of bacterial crude extracts on weed seedlings

The bioassay with ethyl acetate crude extracts of the four bacterial isolates showed that Pseudomonas sp. (isolate 1) gave the highest significant reduction in total biomass fresh weight of Portulac oleracea seedlings, regardless the concentration tested. At a concentration of $5,10,20,30$, and $40 \mathrm{mg} / \mathrm{ml}$ crude extract, the reduction percentage was $16.00,17.46,34.55$, 46.91 and 71.27 , respectively as shown in Table 3 . The second highly active extract was that of Pseudomonas sp. (isolate 2) which gave 51\% reduction at $40 \mathrm{mg} / \mathrm{ml}$. Table 4 is summarizing the total biomass fresh weight of Convolvulus arvensis in response to applying bacterial crude extracts. The highly active extract was that of Xanthomonas sp. which gave $40.34 \%$ reduction in fresh weight at the highest concentration $40 \mathrm{mg} / \mathrm{ml}$, followed by Pseudomonas sp. (isolate 1) which gave $39.37 \%$ reduction. Also, at $40 \mathrm{mg} /$ $\mathrm{ml}$ Bacillus sp. and Pseudomonas sp. (isolate 2) gave 38.36 and $35.58 \%$ reduction in biomass fresh weight.

TABLE 2. Biochemical tests of active bacterial isolates.

\begin{tabular}{lcccc}
\hline & FS15 & PS & BS47 & BRS2 \\
\hline Gram stain & - & - & - & + \\
Urease & - & + & - & - \\
Citrate & + & + & - & + \\
Catalase & + & + & + & + \\
Starch hydrolysis & - & - & + & + \\
Nitrate reduction & + & + & + & - \\
TSI & - & - & - & - \\
MR-VP & - & - & + & - \\
KOH & - & - & - & - \\
Glucose oxidase & + & + & +
\end{tabular}

TABLE 3. Effect of bacterial ethyl acetate crude extracts on total biomass fresh weight (mg) of Portulaca oleracea.

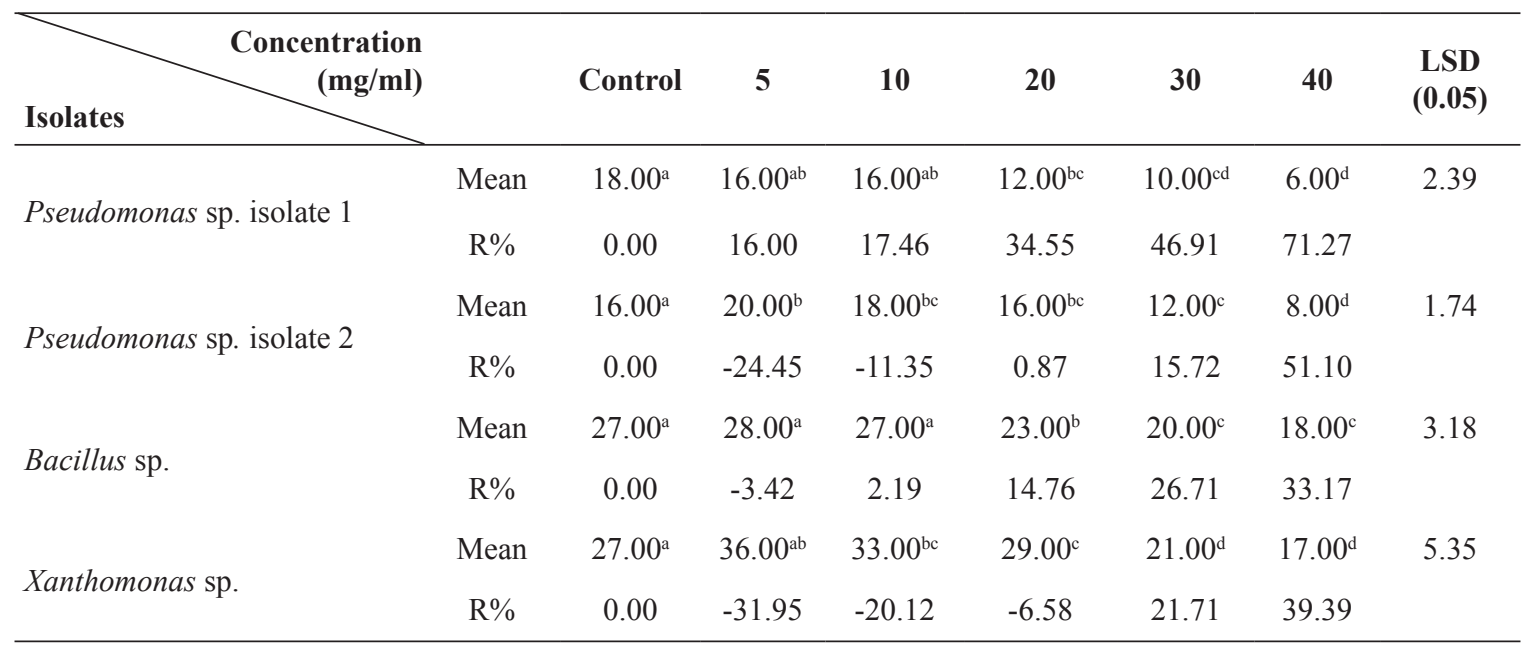

Mean $=$ Average values after seven days, $\mathrm{R} \%=$ rReduction percentage in biomass fresh weight, $\mathrm{LSD}=\mathrm{Lleast}$ significant difference. Values with the same letter in each column do not differ from each other statistically $(\mathrm{P} \leq 0.05)$. 
TABLE 4. Effect of bacterial ethyl acetate crude extracts on total biomass fresh weight (mg) of Convolvulus arvensis.

\begin{tabular}{|c|c|c|c|c|c|c|c|c|}
\hline Isolates $\quad \begin{array}{r}\text { Concentration } \\
(\mathrm{mg} / \mathrm{ml})\end{array}$ & & Control & 5 & 10 & 20 & 30 & 40 & $\begin{array}{c}\text { LSD } \\
(0.05)\end{array}$ \\
\hline \multirow{2}{*}{ Pseudomonas sp. isolate 1} & Mean & $147.00^{\mathrm{a}}$ & $125.00^{\mathrm{b}}$ & $116.00^{c}$ & $109.00^{\mathrm{c}}$ & $101.00^{\mathrm{cd}}$ & $89.00^{\mathrm{d}}$ & 19.18 \\
\hline & $\mathrm{R} \%$ & 0.00 & 15.38 & 21.27 & 26.02 & 31.45 & 39.37 & \\
\hline \multirow{2}{*}{ Pseudomonas sp. isolate 2} & Mean & $238.00^{\mathrm{a}}$ & $190.00^{\mathrm{b}}$ & $183.00^{\mathrm{b}}$ & $172.00^{\mathrm{c}}$ & $163.00^{\mathrm{cd}}$ & $153.00^{\mathrm{d}}$ & 9.55 \\
\hline & $\mathrm{R} \%$ & 0.00 & 20.00 & 23.16 & 27.79 & 31.58 & 35.58 & \\
\hline \multirow{2}{*}{ Bacillus sp. } & Mean & $219.00^{\mathrm{a}}$ & $222.00^{\mathrm{a}}$ & $197.00^{\mathrm{b}}$ & $173.00^{\mathrm{c}}$ & $147.00^{\mathrm{d}}$ & $135.00^{\mathrm{d}}$ & 15.04 \\
\hline & $\mathrm{R} \%$ & 0.00 & -1.37 & 9.89 & 20.85 & 32.73 & 38.36 & \\
\hline \multirow{2}{*}{ Xanthomonas sp. } & Mean & $110.00^{\mathrm{a}}$ & $117.00^{\mathrm{a}}$ & $106.00^{\mathrm{a}}$ & $81.00^{\mathrm{b}}$ & $79.00^{\mathrm{b}}$ & $65.00^{\mathrm{b}}$ & 17.89 \\
\hline & R\% & 0.00 & -6.54 & 3.50 & 25.99 & 28.25 & 40.34 & \\
\hline
\end{tabular}

Quantitive assessment of effective concentration $\left(E C_{50}\right)$

The median effective concentration $\left(\mathrm{EC}_{50}\right)$ was determined as shown in Table 5 from probit curves, while the linear line was generated. Based on $\mathrm{EC}_{50}$ values Pseudomonas sp. isolate 1 showed the lowest value when compared to the other isolates. The $\left(\mathrm{EC}_{50}\right)$ of this isolate was determined on Portulaca oleracea (total biomass fresh weight parameter) by $1.3 \mathrm{mg} / \mathrm{ml}$. The dose response curve of Pseudomonas sp. isolate 1 was shown in Fig. 1.

Identification of the most active isolate by molecular technique

The most potent isolate was identified by $16 \mathrm{~S}$ rDNA gene sequence. The bacterial isolate 99\% identical to Pseudomonas aeruginosa. The phylogenetic tree of the isolate with the nearest strains revealed that it was closely related to Pseudomonas aeruginosa strain NR 113599.1 (Fig. 2).

TABLE 5. Effective concentration $\left(\mathrm{EC}_{50}\right)$ of microbial crude extracts on total biomass fresh weight of weed seedlings.

\begin{tabular}{lcc}
\hline \multirow{2}{*}{ Isolates } & \multicolumn{2}{c}{$\mathbf{E C}_{\mathbf{5 0}}(\mathbf{m g} / \mathbf{m l})$} \\
\cline { 2 - 3 } & Convolvulus arvensis & Portulaca oleracea \\
\hline Pseudomonas sp. isolate 1 & 1.64 & 1.30 \\
Pseudomonas sp. isolate 2 & $\mathrm{~N} . \mathrm{D}$ & 1.63 \\
Bacillus sp. & 1.79 & $\mathrm{~N} . \mathrm{D}$ \\
Xanthomonas sp. & 1.69 & 1.72 \\
\hline
\end{tabular}

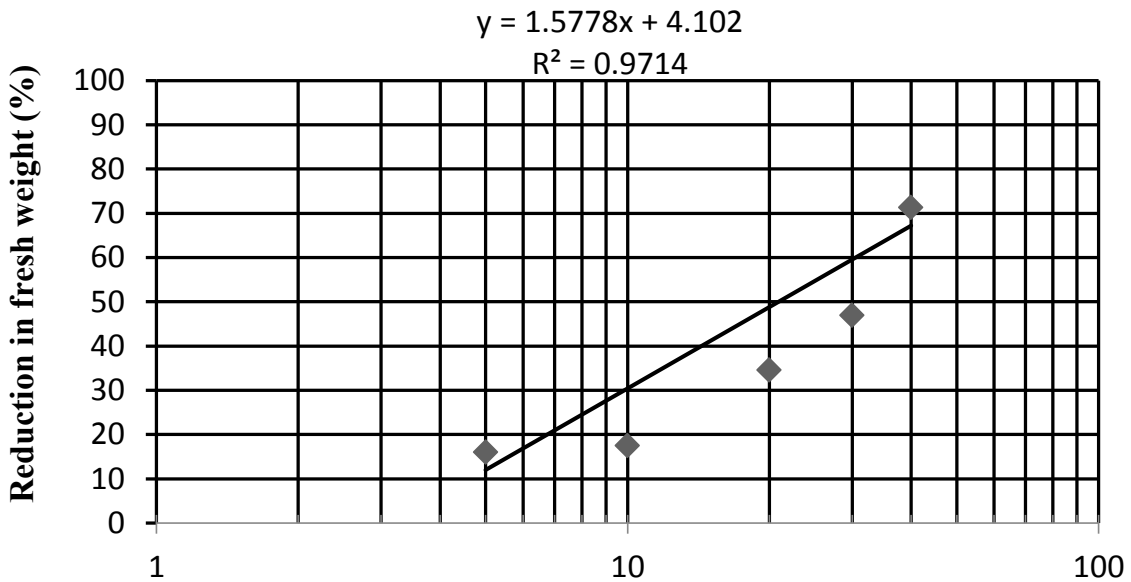

\section{Log concentration}

Fig. 1. Dose response curve of Pseudomonas aeruginosa on Portulaca oleracea total biomass fresh weight. 


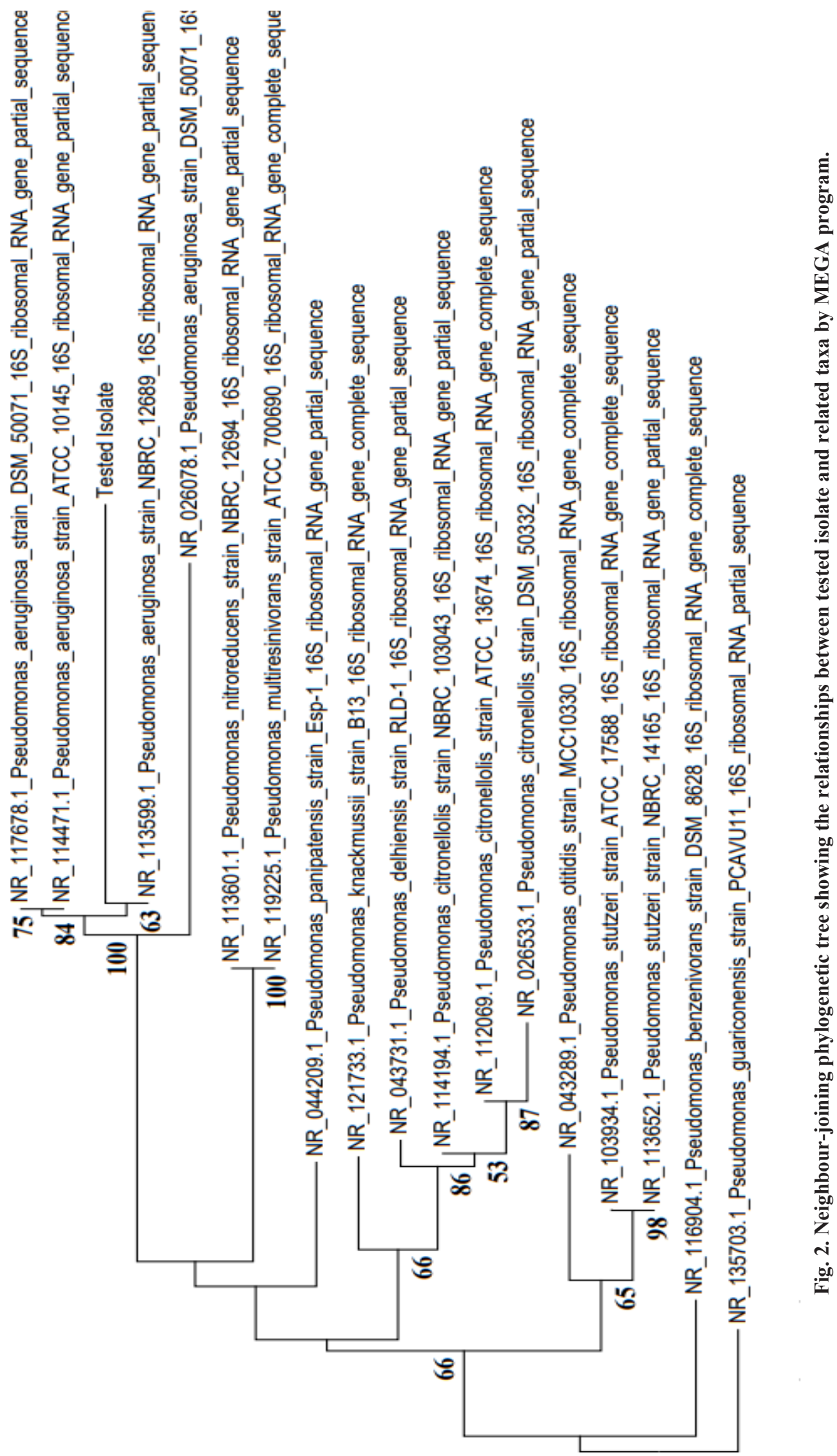




\section{Discussion}

Weed is a concern in both agriculture and ecology and scientists are always testing new natural herbicides in order to improve crop yields and eradicate invasive species without damaging the environment. The ability of bacteria to inhibit growth of various weed taxa in different cropping systems is well documented (Kremer \& Souissi, 2001 and Patil, 2013). In this study, the herbicidal activity of 40 bacterial isolates was evaluated on Portulaca oleracea and Convolvulus arvensis of which four bacterial isolates gave the highest herbicidal effect on seed germination and seedling growth. Preliminary identification based on morphological features and biochemical characterization revealed that two, designated as isolate 1 and isolate 2, were belong to the genus Pseudomonas, meanwhile the other two were members of the genus Bacillus and Xanthomonas. Based on seedling growth bioassay, we identified the high active one through gene sequencing as Pseudomonas aeruginosa. A dose-based activity was reported with highly significant results against Portulaca oleracea rather than Convolvulus arvensis.

In our study, we also reported a high characteristic herbicidal activity of Bacillus sp. and Xanthomonas sp. on Portulaca oleracea and Convolvulus arvensis seeds. There are many assumptions in the literature of the potential herbicidal activity of Bacillus and Xanthomonas sp. based on isolate screening and biological assessments. Pseudomonas aeruginosa has been also alleged to be a source of biologically active agents with high herbicidal activity (Hadizadeh et al., 2014 and Boyette \& Hoagland, 2015). The potential activity of three rhizomicroorganisms (Pseudomonas syringae st.1, Pseudomonas syringae st.2 and Colletotrichum sp.) was reported against Polyogon monspeliensis, Phalaris paradox and Convolvulus arvensis. In this context the ethyl acetate extracts of $P$. syringae st. 2 and Colletotrichum sp. showed inhibitory effects at $120 \mu \mathrm{g} \mathrm{ml}^{-1}$ with a decline in seedling growth reached maximal values. Meanwhile, $C$. arvensis was slightly affected by most treatments except for P. syringae st. 1 which reduced seedling biomass by $22.83 \%$ at $120 \mu \mathrm{g} \mathrm{m}^{-1}$ (Omer \& Balah, 2011). Lakshmi et al. (2015) used Pseudomonas aeruginosa $\mathrm{KC} 1$ in a form of bacterial suspension to inhibit seedling growth of Portulaca oleracea both in vitro and in glasshouse studies where it caused a high reduction in root length and biomass. To a large extent, this is in line with results of our study; treatment with culture filtrate of Pseudomonas aeruginosa resulted in 100\% reduction on seed germination, shoot and root length of Portulaca oleracea while, using the crude ethyl acetate extracts resulted in $71.27 \%$ significant reduction in total biomass fresh weight of seedlings at $40 \mathrm{mg} / \mathrm{ml}$. In this context, Adetunji et al. (2017) proved that the crude extract of Psudomonas aeruginosa had high necrotic activity against Amaranthus hybridus L. and Echinochloa crus galli (L.) Beauv.

The chemical nature of microbe-derived natural products is as varied as the microorganisms themselves (De Luna et al., 2011) which range from simple compounds like cyanide and organic acids (Kremer \& Souissi, 2001) to complex compounds like secondary metabolites (Kroschel \& Elzein, 2004) including plant growth regulators such as auxins and ethylene (De Luna et al., 2005). For the well-studied biological activities, the negative impacts of Pseudomonas aeruginosa against weeds is associated with the production of Hydrogen Cyanide which result in lethality in most cases (Kremer \& Souissi, 2001). HCN inhibits the terminal cytochrome c oxidase in the respiratory chain and binds to metalloenzymes and may have deleterious effects on several plants (Jain \& Das, 2016).

\section{Conclusion}

The use of microbial metabolites produced by Pseudomonas aeruginosa could be promising for the management of weeds in conventional and organic farming to improve yield and enhance food security. Even though the current study gave special attention to assess both cultural filtrates and crude ethyl acetate extracts on two of the most aggressive weeds in the Egyptian agricultural community, further study will be needed to explore the responsible phytotoxins and screening activity under large-scale programs including the effect on non-target organisms and stability under various environmental conditions.

\section{$\underline{\text { References }}$}

Adetunji, C., Oloke, J., Kumar, A., Swaranjit, S., and Akpor, B. (2017) Synergetic effect of rhamnolipid from Pseudomonas aeruginosa $\mathrm{C} 1501$ and phytotoxic metabolite from Lasiodiplodia 
pseudotheobromae C1136 on Amaranthus hybridus L. and Echinochloa crus-galli weeds. Environmental Science and Pollution Research, 24(15), 13700-13709.

Balah, M.A. (2012) Allelopathic potential of Jasonia montana (Wild Plant) to control weeds of family Convolvulaceae. Allelopathy Journal, 29(1), 93106.

Boyette, C.D. and Hoagland, R.E. (2015) Bioherbicidal potential of Xanthomonas campestris for controlling Conyza canadensis. Biocontrol Science and Technology, 25(2), 229-237.

De Luna, L., Stubbs, T., Kennedy, A. and Kremer, R. (2005) Deleterious bacteria in the rhizosphere. In: "Roots and Soil Management: Interactions Between Roots and the Soil", Zobel, R., Wright, S. (Eds.), pp. 233-261. American Society of Agronomy, Madison.

De Luna, L.Z., Kennedy, A.C., Hansen, J.C., Paulitz, T.C., Gallagher, R.S. and Fuerst, E.P. (2011) Mycobiota on wild oat (Avena fatua L.) seed and their caryopsis decay potential. Online Plant Health Progress, Doi: 10.1094/PHP-2011-0210-01-RS.

Ferreira, M.I. and Reinhardt, C.F. (2016) Allelopathic weed suppression in agroecosystems: A review of theories and practices. African Journal of Agricultural Research, 11(6), 450-459.

Gliessman, S.R. (2002) Allelopathy and agroecology. In: "Chemical Ecology of Plants: Allelopathy in Aquatic and Terrestial Ecosystems", Mallik A.U. and Inderjit (Eds.), pp. 173-185.

Hadizadeh, F., Mehrvarz, S.S. and Mirpour, M.S.S. (2014) Effect of Bacillus spp. on seed germination of selected species of the genus Cuscuta (Convolvulaceae). Modern Phytomorphology, 6, 97-101.

Holm, L.G, Plucknett, D.L., Pancho, J.V. and Herberger, J.P. (1991) "The world's Worst weeds: Distribution and Biology". Malabar, FL: Krieer, pp. 98-104. The University Press of Hawaii, Honolulu.

Jain, A. and Das, S. (2016) Insight into the interaction between plants and associated fluorescent Pseudomonas spp. International Journal of Agronomy. DOI: 10.1155/2016/4269010
Javaid, A. (2010) Herbicidal potential of allelopathic plants and fungi against Parthenium hysterophorus: A review. Allelopathy Journal, 25(2), 331-334.

Javaid, A. and Ali, S. (2011) Herbicidal activity of culture filtrates of Trichoderma spp. against two problematic weeds of wheat. Natural Product Research, 25(7), 730-740.

Johnston, A. and Booth, C. (1983) "Plant Pathologist's Pocket Book"'. $2^{\text {nd }}$ edn., Surrey, Commonwealth Agricultural Bureaux, UK.

Kremer, R.J. (2006) The role of allelopathic bacteria in weed management. In: "Allelochemicals: Biological Control of Plant Pathogens and Diseases", pp. 143155. Springer, Dordrecht.

Kremer, R.J. and Souissi, T. (2001) Cyanide production by rhizobacteria and potential for suppression of weed seedling growth. Current Microbiology, 43(3), 182-186.

Kroschel, J. and Elzein, A. (2004) Bioherbicidal effect of fumonisin B1, a phytotoxic metabolite naturally produced by Fusarium nygamai, on parasitic weeds of the genus Striga. Biocontrol Science and Technology, 14(2), 117-128.

Landa, B.B., Hervás, A., Bettiol, W. and JiménezDíaz, R.M. (1997) Antagonistic activity of bacteria from the chickpea rhizosphere against Fusarium oxysporum f. sp. Ciceris. Phytoparasitica, 25(4), 305-318.

Lakshmi, V., Kumari, S., Singh, A. and Prabha, C. (2015) Isolation and characterization of deleterious Pseudomonas aeruginosa $\mathrm{KC1}$ from rhizospheric soils and its interaction with weed seedlings. Journal of King Saud University-Science, 27(2), 113-119.

Moneim, A.E.A., Dkhil, M.A. and Al-Quraishy, S. (2013) The potential role of Portulaca oleracea as a neuroprotective agent in rotenone-induced neurotoxicity and apoptosis in the brain of rats. Pesticide Biochemistry and Physiology, 105(3), 203-212.

Omer, A.M. and Balah, M.A. (2011) Using of rhizomicrobes as bioherbicides of weeds. Global Journal of Biotechnology and Biochemistry, 6(3), 102-111.

Omer, Z.S., Jacobsson, K., Eberhard, T.H. and 
Johansson, L.K.H. (2010) Bacteria considered as biocontrol agents to control growth of white clover on golf courses. Acta Agriculture Scandinavica Section B-Soil and Plant Science, 60(3), 193-198.

Patil, V.S. (2013) Rhizospheric bacteria with the potential for biological control of Parthenium hysterophorus. Journal of Chemical, Biological and Physical Sciences, 3(4), 2679.

Patil, V.S. (2014) Isoaltion, characterization and identification of rhizospheric bacteria with the potential for biological control of Sida acuta. Journal of Environmental Research and Development, 8(3), 411.

Prescot, L.M., Harley, J.P. and Klein, D.A. (1993) "Microbiology", $2^{\text {nd }}$ ed. Dubuque: WCB Communications, Inc., 912p.

Radhakrishnan, R., Park, J.M. and Lee, I.J. (2016) Enterobacter sp. I-3, a bio-herbicide inhibits gibberellins biosynthetic pathway and regulates abscisic acid and amino acids synthesis to control plant growth. Microbiological Research, 193, 132139.

Saitou, N. and Nei, M. (1987) The neighbor-joining method: A new method for reconstructing phylogenetic trees. Molecular Biology and Evolution, 4(4), 406-425.
Sindhu, S.S. and Sehrawat, A. (2017) Rhizosphere microorganisms: Application of plant beneficial microbes in biological control of weeds. In: "Microorganisms for Green Revolution". pp. 391430. Springer, Singapore.

Smith, G.F. and Figueiredo, E. (2010) Purslane (Portulaca oleracea, Portulacaceae) in southern Africa: More useful than most succulents. Cactus \& Succulent Journal (U.S.), 82, 116-121.

Snedecor, G.W. and Cochran, W.G. (1990) "Statistical Methods". $8^{\text {th }}$ ed., Iowa State Univ. Press, Ames, Iowa, USA.

Tamura, K., Peterson, D., Peterson, N., Stecher, G., Nei, M. and Kumar, S. (2011) MEGA5: Molecular evolutionary genetics analysis using maximum likelihood, evolutionary distance, and maximum parsimony methods. Molecular Biology and Evolution, 28(10), 2731-2739.

Weissmann, R. and Gerhardson, B. (2001) Selective plant growth suppression by shoot application of soil bacteria. Plant Soil, 234, 159-170.

(Received 5/8/2018; accepted 21/10/2018)

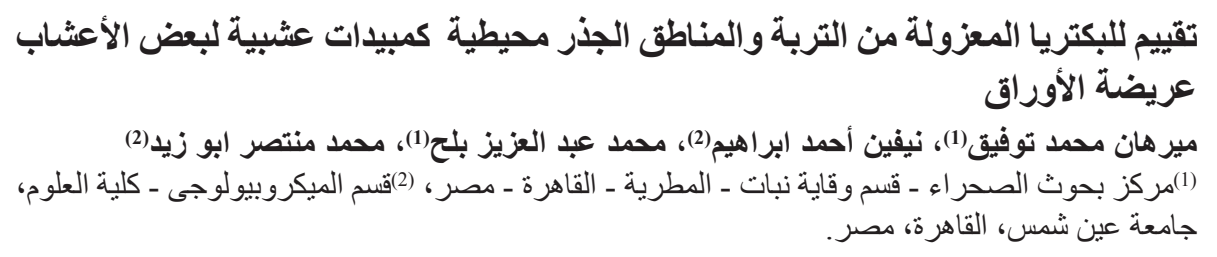

يعتبر استخدام البكتريا فى المكافحة الحيوية للحشائش بديل صديق للبيئة للقضاء على مشكلة الحشائش و تقليل

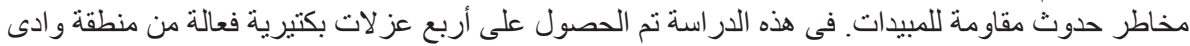

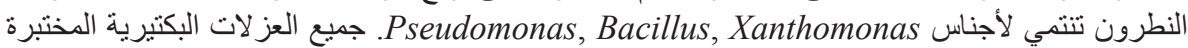

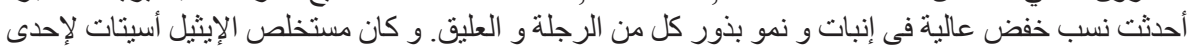

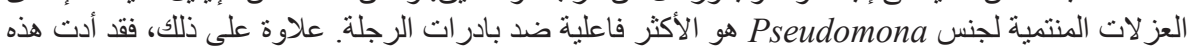

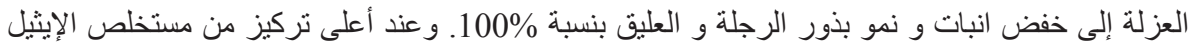

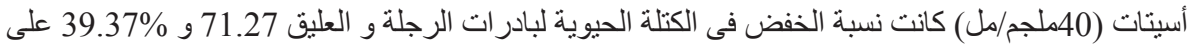

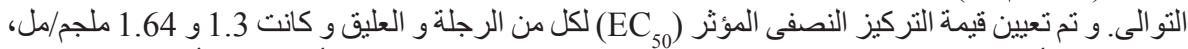

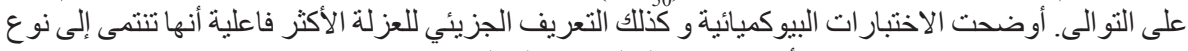

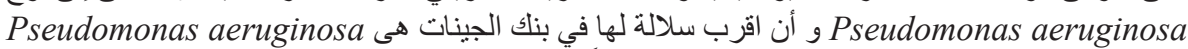
strain NR 113599.1 Pseudomonas aeruginosa الحشائش العريضة. 